\title{
ISLAM DAN NEGARA \\ (Sebuah Catatan Pengantar)
}

\author{
Hadi Daeng Mapuna
}

Fakultas Syariah dan Hukum Universitas Islam Negeri (UIN) Alauddin Makassar

\begin{abstract}
Discussion of Islam and the State, both on the necessity of establishing an Islamic State and making Islam the basis of a State regardless of the form of the State, still seems to continue. The discourse sometimes sounded loud but at other times it sounded faintly. Depends on the trigger momentum.

An in-depth study is needed, especially in relation to the current situation and condition so as to broaden the horizons and bring effect to the actualization of Islamic teachings in all aspects of life.

Keywords:

Islam, State

Abstrak

Pembicaraan mengenai Islam dan Negara, baik mengenai perlunya mendirikan Negara Islam maupun menjadikan Islam sebagai dasar sebuah Negara tanpa memandang bentuk Negara itu, tampaknya masih akan terus berlanjut. Diskursus itu kadang-kadang terdengar begitu riuh namun di saat yang lain terdengar sayup-sayup. Tergantung pada momentum pemicunya.

Diperlukan kajian yang mendalam, khususnya dikaitkan dengan situasi dan kondisi terkini sehingga dapat lebih memperluas wawasan dan membawa efek demi teraktualisasinya ajaran-ajaran Islam dalam segala aspek kehidupan.
\end{abstract}

Kata Kunci:

Islam, Negara

\section{A. Pendahuluan}

$\mathrm{P}$ erdebatan mengenai Islam dan Negara ini sesungguhnya telah berlangsung cukup lama. Setidaknya telah dimulai sejak berakhirnya sistem khilafah di Turki (1924). Namun demikian, hingga kini tema ini tetap menarik dibicarakan dan seolah-seolah tidak pernah kehilangan relevansinya.

Fokus perdebatan para intelektual muslim maupun non muslim yang memberi perhatian pada masalah ini adalah apakah Islam harus menjadi landasan atau dasar bagi sebuah Negara. Atau pertanyaan yang lebih awal adalah, apakah Islam mewajibkan umatnya membentuk sebuah Negara dan pemerintahan sendiri terpisah 
dari umat-umat lain? Dan, apakah ada model Negara Islam yang baku yang pernah dicontohkan, baik oleh Rasulullah saw., maupun khulafaur rasyidin yang harus ditiru saat ini.

Tulisan ini akan mengemukakan beberapa pemikiran sebagai jawaban atas pertanyaan-pertanyaan di atas. Dari tulisan ini diharapkan dapat memperluas wawasan mengenai tema ini meskipun tulisan ini masih berupa catatan awal.

\section{B. Konsep Negara Dalam Islam}

Berbicara mengenai apakah Islam mewajibkan umatnya membentuk sebuah Negara, tentu rujukannya adalah al-Qur'an dan alhadis, dua sumber utama ajaran Islam. Al-Qur'an mengandung sabda Tuhan (kalam Allah) yang diturunkan melalui wahyu kepada Nabi Muhammad saw., untuk dijadikan pedoman hidup bagi manusia. ${ }^{1}$ Sedangkan hadis adalah tafsir terhadap Al-Qur'an yang berasal dari Nabi Muhammad saw., baik berupa pernyataan, perbuatan maupun taqrir. ${ }^{2}$

Al-Qur'an diyakini sebagai kitab yang sempurna ${ }^{3}$ yang tidak ada keraguan di dalamnya.4 Al-Qur'an diturunkan untuk menjadi pedoman umat Islam dalam menata hidup dan kehidupannya di muka bumi. Al-Qur'an mengandung petunjuk bagi manusia dan penjelasan terhadap petunjuk-petunjuk itu. ${ }^{5}$

Kesempurnaan Al-Qur'an disepakati seluruh umat Islam. Namun, apakah kesempurnaan Al-Qur'an itu meliputi seluruh aspek kehidupan dan memberi penjelasan yang detail ataukah hanya mengandung ajaran-ajaran dasar yang bersifat global, umat Islam terbagi menjadi dua kelompok. Pertama, sebagaimana ditulis Harun Nasution, mengakui bahwa Al-Qur'an mencakup segala-galanya. Tidak satu hal pun yang tidak disebut dan dijelaskan di dalamnya. Di dalamnya terdapat penjelasan tentang system politik, system ekonomi, system keuangan, system kemasyarakatan, system pertanian, perindustrian dan sebagainya. ${ }^{6}$

Kelompok kedua berlawanan dengan kelompok pertama di atas. Mereka menyatakan bahwa Al-Qur'an tidaklah mengandung segala-galanya. Yang dimaksud dengan penyempurnaan agama dalam QS. Al-Maidah ayat 3 (Pada hari ini telah Kusempurnakan untukmu agamamu, dan telah Kucukupkan kepadamu nikmatKu dan telah Kuridhoi Islam itu sebagai agamamu) tidaklah berarti penyempurnaan dengan segala ilmu pengetahuan, tekhnologi dan sistem kemasyarakatan manusia dalam segala aspek. Penyempurnaan mengandung arti lain, yaitu dalam arti hokum, ajaran atau dasar agama atau halam serta haram. Rasyid Ridha berpendapat bahwa yang

${ }^{1}$ Harun Nasution, Islam Rasional (Cet. II; Bandung: Mizan, 1995), 17.

${ }^{2}$ Ulama hadis pada umumnyaberpendapat bahwa yang dimaksud dengan hadis ialah segala sabda, perbuatan dan taqrir dan hal ikhwal yang disandarkan kepada Nabi Muhammad saw. Selengkapnya lihat, Syuhudi Ismail, Kaedah Kesahihan Sanad Hadis (Jakarta: Bulan Bintang, 1988), 25.

${ }^{3}$ QS. 5:3; 6:38.

${ }^{4}$ QS. 2:2.

${ }^{5}$ QS. 2:284; QS. 16:89. (Dan Kami turunkan Kitab itu untuk menjelaskan segala-galanya).

${ }^{6}$ Lihat, Harun Nasution, Islam Rasional (Cet. II; Bandung: Mizan, 1995), 25. 
dimaksud oleh ayat itu ialah penyempurnaan iman, hukum, budi pekerti, ibadah dengan terperinci dan muamalat dalam garis besar. ${ }^{7}$

Fakta-fakta mengenai ayat-ayat Al-Qur'an sendiri juga turut membantah pandangan bahwa al-Qur'an mengandung perincian mengenai berbagai hal. Menurut Ahmad Amin, jumlah ayat mengenai hidup kemasyarakatan hanya sekitar 200 ayat. Menurut Abdul Wahab Khallab dalam kitabnya 'Ilmu Ushul al-Figh, ayatayat mengenai kemasyarakatan terdapat sekitar 228 ayat. Perinciannya adalah sebagai berikut:

Menyangkut kekeluargaan, perkawinan, perceraian, hak waris dan sebagainya (70 ayat); Perdagangan,Gadai, perekonomian, jual beli, sewa-menyewa, pinjam meminjam, perseroan, kontrak, dan sebagainya (70 ayat); masalah pidana (30); hubungan orang Islam dengan orang bukan Islam (25); pengadilan (13); hubungan orang kaya dengan orang miskin (10); dan masalah ketatanegaraan (10). ${ }^{8}$

Fakta-fakta di atas menunjukkan bahwa masih ada beberapa hal yang tidak disebutkan, yaitu, antara lain, masalah keuangan, perindustrian, dan pertanian. Masalah kenegaraan memang disebut, tetapi ayat-ayat itu tidak menjelaskan sistem pemerintahan yang harus dijalankan oleh umat Islam. Di dalamnya tidak disebut apakah pemerintahan harus berbentuk kerajaan atau republic. Yang dijelaskan adlah dasar-dasar yang harus dipakai dalam mengatur Negara. ${ }^{9}$

Dari uraian di atas dan berdasarkan penelusuran penulis, tidak ditemukan dalil yang mewajibkan umat Islam untuk mendirikan sebuah Negara. Akan tetapi, prinsip-prinsip dasar dari Al-Qur'an dapat diterapkan dalam pengelolaan Negara, baik yang berbentuk republik maupun monarki.

Pertanyaan yang kemudian muncul, bagaimana dengan Negara Madinah yang dibentuk dan dipimpin oleh Nabi Muhammad saw? Bukankah itu merupakan pengejawantahan dari sebuah perintah Allah swt., yang diturunkan kepadanya?

Pada saat nabi Muhammad berada di Madinah --disebut sebagai periode Madinah - (622-632), diakui oleh banyak kalangan memiliki dua peranan sekaligus, yaitu sebagai pemimpin agama dan pemimpin Negara. Thomas W. Arnold sebagaimana dikutip Musdfa Mulia, mengatakan bahwa posisi nabi di Madinah adalah sebagai pemimpin agama yang sekaligus juga kepala Negara. ${ }^{10}$

Pengakuan serupa juga datang dari Fazlurrahman, tokoh Neo-modernisme Islam. Menurutnya, masyarakat Madinah yang dipimpin oleh Nabi itu merupakan suatu Negara dan pemerintahan yang menyebabkan terbentuknya suatu umat muslim. ${ }^{11}$

${ }^{7}$ Tafsir Al-Manar, Jil. VI, 155

${ }^{8}$ Abdul Wahab Khallaf, 'Ilmu Ushul al-Fiqh (Kairo: Mathba'ah al-Nashr, 1956), 35-36.

${ }^{9}$ Lihat, Harun Nasution, Islam Rasional (Cet. II; Bandung: Mizan, 1995), 27.

${ }^{10}$ Lihat, Musda Mulia, Negara Islam (Jakarta: Kata Kita, 2010), 16-17. Arnold menulis pandangannya tersebut dalam bukunya, The Caliphate, yang diterbitkan di London pada 1965.

${ }^{11}$ Musda Mulia, Negara Islam (Jakarta: Kata Kita, 2010), 17. 
Bagi penulis, terbentuknya Negara Madinah di bawah kepemimpinan Muhammad saw., bukan sebuah manifestasi dari perintah atau kewajiban agama, melainkan lebih merupakan kebutuhan yang muncul seiring dengan semakin bertambah banyaknya umat Islam pada saat itu. ${ }^{12}$ Meskipun demikian, dalam mengelolah Negara dan pemerintahannya, Muhammad tidak terbebas dari control wahyu Allah swt. Itulah sebabnya, para penulis umumnya menyebut bahwa Negara yang dibentuk Nabi saw., adalah Negara teokrasi dalam arti Negara yang kedaulatannya ada pada Tuhan. ${ }^{13}$

Meskipun tidak ada dalil yang memerintahkan umat Islam membentuk sebuah Negara (Negara Islam), namun, perkembangan kehidupan yang demikian kompleks, relasi antar manusia yang beragam, sistem kehidupan bernegara yang juga tidak sederhana -yang sesekali memunculkan ketegangan-ketegangan, baik antar anggota masyarakat maupun antara masyarakat dan Negara-mendorong sejumlah pemikir dan aktivis politik Islam untuk menjadikan Islam sebagai landasan atau dasar bagi sebuah Negara. Mereka mendorong berdirinya Negara Islam. Mereka meyakini bahwa Negara yang berlandaskan Islam akan mampu mengatasi berbagai permasalahan maupun ketegangan-ketegangan dan hubungan-hubungan yang tidak harmonis dalam kehidupan bermasyarakat.

\section{Posisi Islam dalam Negara}

Diskursus mengenai Negara Islam atau Negara yang berlandaskan Islam, baru muncul setelah berakhirnya sistem khilafah di Turki (1924). Sejumlah pemikir politik Islam terlibat dalam perdebatan mengenai hubungan agama (Islam) dan Negara. Fokus perdebatan tersebut adalah apakah ajaran Islam mengandung atau membawa aturan-aturan mengenai kenegaraan atau tidak?

Dalam perkembangan selanjutnya, diskursus tersebut melahirkan tiga corak atau aliran pemikiran. Pertama, aliran yang memandang bahwa ajaran Islam adalah kaffah (sempurna). Seluruh aspek kehidupan umat manusia diatur di dalamnya, termasuk mengenai aturan kenegaraan. Oleh karena itu, umat Islam hendaknya kembali kepada sistem ketatanegaraan Islam, seperti yang pernah dipraktekkan oleh Nabi dan Khulafa' Rasyidin.

Mereka beranggapan bahwa -sebagaimana ditulis Bahtiar Effendy-- Islam harus menjadi dasar Negara dan syariah harus diterima sebagai konstitusi Negara. Gagasan tentang Negara bangsa (nation state) bertentangan dengan konsep ummah (komunitas Islam) yang tidak mengenal batas politik atau kedaerahan. ${ }^{14}$

Pemikir politik Islam yang tergolong dalam kategori ini antara lain; Rasyd Ridha dan Sayyid Qutb dari Mesir; Abu al-A'la al-Maududi dan 'Ali an-Nadvi dari

\footnotetext{
${ }^{12}$ Pada masa awal, atau disebut sebagai periode Mekkah (611-622) pengikut Muhammad hanya terdiri dari sejumlah kecil penduduk Mekkah. Mereka merupakan kelompok yang lemah yang tidak memiliki wilayahdan kedaulatan. Oleh karena itu, pada masa itu Nabi hanya berperan sebagai pemimpin agama.

${ }^{13}$ Lihat, Musda Mulia, Negara Islam (Jakarta: Kata Kita, 2010), 17.

${ }^{14}$ Lebih lengkap, baca, Bahtiar Effendy, Isalm dan Negara (Cet. II; Jakarta: Paramadina, 2009), 13-14.
} 
Pakistan. Di Indonesia, corak pemikiran ini tampaknya dianut oleh M. Natsir, M. Rasyidi, Abdul Kahar Muzakkir, Abikusno Tjokrosoejoso dan A. Wahid Hasyim. ${ }^{15}$ Dalam konteks Indonesia, pendukung corak pemikiran ini telah berjuang, bahkan, sebelum Indonesia merdeka. Pada sekitar tahun tigapuluhan, Muhammad Natsir, yang disebut Bahtiar sebagai articulator penting dari gagasan ini, telah terlibat dalam perdebatan dengan Soekarno tentang hal ini. ${ }^{16}$

Lebih jauh Bahtiar menulis bahwa gagasan menjadikan Islam sebagai dasar Negara juga muncul dalam siding BPUPKI, ketika para pendiri republik tengah menyaipakn "perangkat lunak" kenegaraan Indonesia. Wakil-wakil umat Islam (Islam nasionalis) saat itu tidak saja memperjuangkan agar Islam menjadi dasar Negara, tetapi juga memperjuangkan pemikiran Islam sebagai agama Negara, presiden harus seorang Islam, Negara harus memiliki aparat-aparat dan badanbadan yang relevan untuk menerapkan hukum Islam, dan kemungkinan Jumat dijadikan sebagai hari libur nasional. ${ }^{17}$

Tulisan Bahtiar di atas menunjukkan bahwa para pendukung gagasan ini tampaknya sangat menekankan pada aspek formal dari sebuah Negara Islam (Indonesia) yang akan dibentuk, walaupun pada akhirnya tidak berhasil.

Kedua, aliran atau corak pemikiran yang berpendapat bahwa Islam adalah agama yang semata-mata mengurusi hubungan antar manusia dan Tuhan serta masalah-masalah kehidupan di akhirat. Di dalam ajaran-ajarannya sama sekali tidak ditemukan ketentuan yang mengatur masalah politik atau ketatanegaraan. Menurut aliran ini, Nabi Muhammad saw., diutus Tuhan untuk mengajak manusia supaya percaya kepada Tuhan yang Maha Esa dan kembali kepada kehidupan yang mulia dengan menjunjung tinggi budi pekerti luhur. Nabi tidak pernah diperintahkan untuk mendirikan dan mengepalai suatu Negara. ${ }^{18}$

Tokoh utama aliran pemikiran yang kedua ini adalah 'Ali 'Abd a-Raziq (18881966). Pemikirannya mengenai khiläfah dan pemerintahan dituangkan dalam bukunya al-Islam wa Ushul al-Hukm, sempat menghebohkan masyarakat Mesir. Hal itu terjadi pada tahun 1925. Di dalam bukunya tersebut, 'Ali 'Abd al-Raziq menegaskan bahwa tidak ada satu dalil pun, baik dari Al-Qur'an maupun Hadis yang mendukung pernyataan bahwa Nabi saw., diutus untuk membentuk Negara atau kerajaan. ${ }^{19}$

Syariat Islam menurut al-Raziq semata-mata bercorak spiritual yang tidak memiliki kaitan dengan hukum dan praktik duniawi. Islam tidak mempunyai kaitan apapun dengan sistem pemerintahan pada periode Nabi maupun al-Khulafa' alRasydin. Dia menolak keras pendapat bahwa Nabi pernah mendirikan Negara

\footnotetext{
${ }^{15}$ Bahtiar Effendy, Jalan Tengah Politik Islam (Jakarta: Ushul Press, 2005), 34.

${ }^{16}$ Bahtiar Effendy, Jalan Tengah Politik Islam (Jakarta: Ushul Press, 2005), 34.

${ }^{17}$ Bahtiar Effendy, Jalan Tengah Politik Islam (Jakarta: Ushul Press, 2005), 34.

${ }^{18}$ Lihat, Musda Mulia, Negara Islam (Jakarta: Kata Kita, 2010), 50-51.

${ }^{19}$ Lihat, Musda Mulia, Negara Islam (Jakarta: Kata Kita, 2010), 50-51.
} 
Islam. $^{20}$ Terhadap pendapatnya tersebut, Antony Black mengomentari bahwa itu akan membebaskan institusi-institusi politik dan banyak praktik social, legal, dan politik secra pasti dari batasan-batasan syariat. ${ }^{21}$

Pemikiran al-Raziq tersebut tampaknya mendapat apresiasi dari Abdullah-i Ahmed an-Naim, seorang pemikir muslim kontemporer kelahiran Sudan. An-Naim meneruskan pemikiran-pemikiran al-Raziq secara progresif dan lebih luas. Ia mengatakan bahwa dari periode Islam awal masa Nabi Muhammad, masa ke-empat khalifah Rasyidun, Dinasti Umayyah, Dinasti Abbasiyah hingga Dinasti Utsmaniyah, bahkan sampai awal abad ke-20, semuanya mengacu pada tatanan sekuler.

Berdasarkan realitas tersebut, an-Naim menegaskan bahwa pemisahan Islam dan Negara secara kelembagaan sangat perlu agar syariat dapat berperan positif dan mencerahkan bagi umat Islam. Selain itu, prinsip syariat akan kehilangan otoritas dan nilai agamanya apabila dipaksakan Negara. ${ }^{22}$

Selain an-Naim, pemikiran al-Raziq juga didukung oleh Abied al-Jabiri, pemikir Islam dari Maroko. Dalam bukunya al-Dìn wa al-Dawlah wa Thatbì alSyari'ah, mengajukan pertanyaan retoris berkaitan dengan system pemerintahan Nabi yang kemudian diteruskan oleh khulafa' al-Rasyidin. "Seandainya Islam menyediakan rumusan baku menyangkut system pemerintahan, mengapa para sahabat mengalami kebingungan pasca wafatnya Nabi. Hal ini membuktikan bahwa model pemerintahan pasca Nabi adalah bentuk dari sebuah penalaran atau hasil dari negosiasi, bukan merupakan ketentuan ilahi. ${ }^{23}$

Di Indonesia, tokoh pemikir dan intelektual Muslim yang sejalan dengan pemikiran 'Ali 'Abd al-Raziq antara lain; Nurcholis Madjid, Abdurrahman Wahid, Harun Nasution dan Munawir Sjadzali. Mereka dipandang menjadi pelopor dalam meredakan ketegangan politik antara Islam dan Negara melalui berbagai pernyataan ide dan aksi politik.

Para pemikir dan aktivis politik muslim tersebut mengusung gagasan utama sekularisasi, yang untuk pertama kalinya dilontarkan oleh Nurcholis Madjid. Bagi Cak Nur, demikian Nurcholis Madjid biasa disapa, Negara adalah salah satu segi kehidupan duniawi, yang dimensinya adalah rasional dan kolektif. Sedangkan agama adalah aspek kehidupan lain yang dimesinya adalah spiritual dan pribadi.

${ }^{20}$ Lihat, Lili Romli, Islam Yes Partai Islam Yes; Sejarah Perkembangan Partai-Partai Islam di Indonesia (Yogyakarta: Pustaka Pelajar, 2006), 25. 'Ali 'Abd al-Raziq, al-Islam wa Ushul al-Hukm (Kairo: Matba'ah Mishr Syirkah Musahamah Mishriyah, 1925).

${ }^{21}$ Antony Black, Pemikiran Politik Islam; Dari Masa Nabi Hingga Masa Kini (Jakarta: Serambi, 2006), $572-573$

${ }^{22}$ Lebih jauh lihat, Abdullah-i Ahmed an-Naim, Dekonstruksi Syariat; Wacana Kebebasan Sipil, Hak Asasi Manusia dan Hubungan Internasional dalam Islam (Yogyakarta: LKiS, 1994), 84. Lihat Juga, buku anNaim yang lain, Islam dan Negara Sekuler; Menegosiasikan Masa Depan Syariah (Bandung: Mizan, 2007$), 18$.

${ }^{23}$ Imam Wahyudin, "Syariat Sebagai Hukum Sekuler,” www.web.uct.ac.za. 
Antara agama dan Negara memang tidak bisa dipisahkan, namun antara keduanya tetap harus dibedakan dalam dimensi dan cara pendekatannya. ${ }^{24}$

Mencermati alur pemikiran kelompok kedua atau kelompok sekuler tersebut, tampak bahwa mereka ingin membebaskan urusan-urusan kenegaraan yang bersifat duniawi dari agama yang bersifat ukhrawi. Urusan agama adalah urusan pribadi yang tidak boleh dicampurbaurkan dengan urusan kenegaraan.

Secara sepintas corak pemikiran ini mengesampingkan agama. Itulah sebabnya kelompok tradisionalis konservatif menolak dengan keras sekularisasi yang dianggap identik dengan sekularisme. Mereka menanggapi wacana tersebut dengan kekhawatiran akan terjadi sekularisme seperti di Turki, terjadinya bid'ah-bid'ah di dalam syariat dan aqidah, ijtihad yang membabi buta, dan penafsiran bebas akan hukum-hukum Islam yang dikhawatirkan bisa menyebabkan pragmatisme di dalam masyarakat. $^{25}$

Bila dua corak pemikiran yang dibahas terdahulu berada pada posisi saling berhadap-hadapan, maka corak pemikiran ketiga berpandangan bahwa Islam bukanlah agama yang semata-mata mengatur hubungan manusia dengan Tuhan, tetapi bukan pula agama yang serba lengkap dalam arti ajarannya mencakup segala aspek kehidupan secara rinci. Islam cukup memberikan prinsip-prinsip dasar yang dapat dipedomani manusia dalam menata hidup dan kehidupannya, baik dalam berhubungan dengan Tuhan maupun berhubungan dengan sesama manusia (masyarakat). ${ }^{26}$

Corak pemikiran ini oleh Musda Mulia disebutnya sebagai corak pemikiran reformis. Kelompok pemikir reformis ini menjadi penengah antara dua corak pemikiran yang berlawanan secara diametral sebagaimana telah diuraikan terdahulu. Pendukung aliran pemikiran ini antara lain dapat disebutkan, Muhammad Husain Haikal (1888-1956). Menurut Munawir Sjadzali, Haikal dapat dikelompokkan ke dalam aliran ini karena ia berpendapat bahwa benar Islam bukanlah agama yang serba mencakup tetapi tidak berarti bahwa Islam hanyalah agama yang mementingkan ritual semata dan mengesampingkan urusan-urusan duniawi. ${ }^{27}$

\footnotetext{
${ }^{24}$ Lihat, Budhy Munawar Rachman, Argumen Islam untuk Sekularisme, Islam Progresif dan Perkembangan Diskursusnya (Jakarta: Grasindo, 2010), 110.

${ }^{25}$ Gagasan Cak Nur juga disalahpahami bahkan oleh teman-teman dekatnya sendiri, seperti, Buya Ismail hasan Metarium, Sulastomo, Endang Saefuddin Anshory dan Amin Rais. Dan yang paling keras kritiknya terhadap Cak Nur adalah Muhammad Natsir dan Muhammad Rusydi. Selengkapnya, baca, Budhy Munawar Rachman, Argumen Islam untuk Sekularisme, Islam Progresif dan Perkembangan Diskursusnya (Jakarta: Grasindo, 2010), 103.

${ }^{26}$ Lihat, Musda Mulia, Negara Islam (Jakarta: Kata Kita, 2010), 22.

${ }^{27}$ Intisari pandangan Muhammad Husain Haikal tersebut termuat dalam bukunya al-Hukumah alIslamiyyah. Menurut catatan Musda Mulia, buku ini mulanya merupakan sekumpulan makalah tentang dasardasar politik, ekonomi, dan sosial di dalam Islam yang ditulis pada tahun 1942. Sebagian besar isinya telah disiarkan melalui radio atau ditulis dalam surat kabar. Lihat, Musda Mulia, Negara Islam (Jakarta: Kata Kita, 2010), 275, catatan kaki nomor 19.
} 


\section{Penutup}

Pembicaraan mengenai Islam dan Negara, baik mengenai perlunya mendirikan Negara Islam maupun menjadikan Islam sebagai dasar sebuah Negara tanpa memandang bentuk Negara itu, tampaknya masih akan terus berlanjut. Diskursus itu kadang-kadang terdengar begitu riuh namun di saat yang lain terdengar sayupsayup. Tergantung pada momentum pemicunya.

Diperlukan kajian yang mendalam, khususnya dikaitkan dengan situasi dan kondisi terkini sehingga dapat lebih memperluas wawasan dan membawa efek demi teraktualisasinya ajaran-ajaran Islam dalam segala aspek kehidupan.

Wallahu a'lam.

\section{Daftar Bacaan}

Black, Antony. Pemikiran Politik Islam; Dari Masa Nabi Hingga Masa Kini. Jakarta:

Serambi, 2006.

Effendy, Bahtiar. Isalm dan Negara. Cet. II; Jakarta: Paramadina, 2009.

Effendy, Bahtiar. Jalan Tengah Politik Islam. Jakarta: Ushul Press, 2005.

Ismail, Syuhudi. Kaedah Kesahihan Sanad Hadis. Jakarta: Bulan Bintang, 1988.

Khallaf, Abdul Wahab. 'Ilmu Ushul al-Fiqh. Kairo: Mathba'ah al-Nashr, 1956.

Mulia, Musda. Negara Islam. Jakarta: Kata Kita, 2010.

an-Naim, Abdullah-i Ahmed. Dekonstruksi Syariat; Wacana Kebebasan Sipil, Hak Asasi

Manusia dan Hubungan Internasional dalam Islam. Yogyakarta: LKiS, 1994.

an-Naim, Abdullah-i Ahmed. Islam dan Negara Sekuler; Menegosiasikan Masa Depan Syariah. Bandung: Mizan, 2007.

Nasution, Harun. Islam Rasional. Cet. II; Bandung: Mizan, 1995.

Rachman, Budhy Munawar. Argumen Islam untuk Sekularisme, Islam Progresif dan Perkembangan Diskursusnya. Jakarta: Grasindo, 2010.

al-Raziq, 'Ali 'Abd. al-Islam wa Ushul al-Hukm. Kairo: Matba'ah Mishr Syirkah Musahamah Mishriyah, 1925.

Romli, Lili. Islam Yes Partai Islam Yes; Sejarah Perkembangan Partai-Partai Islam di Indonesia. Yogyakarta: Pustaka Pelajar, 2006.

Tafsir Al-Manar, Jil. VI, 155

Wahyudin, Imam "Syariat Sebagai Hukum Sekuler," www.web.uct.ac.za. 